\title{
Correction to: Following in their footsteps: an analysis of the impact of successive migration on rural household welfare in Ghana
}

Eva-Maria Egger ${ }^{1 *}$ and Julie Litchfield ${ }^{2}$

* Correspondence: E.Egger@ifad.org

The original article can be found online at https://doi.org/10.1186/ s40176-018-0136-4

${ }^{1}$ International Fund for Agricultural Development, Rome, Italy

Full list of author information is available at the end of the article

\section{Correction to: IZA J Dev Migr}

https://doi.org/10.1186/s40176-018-0136-4

The original version of this article (Egger and Litchfield 2019) has been published with an incorrect copyright holder and license text. The original publication of this article has been updated to correct this.

The copyright holder and license text were originally provided as:

- C The Author(s). 2019 Open Access This article is distributed under the terms of the Creative Commons Attribution 4.0 International License (http://creativecommons. org/licenses/by/4.0/), which permits unrestricted use, distribution, and reproduction in any medium, provided you give appropriate credit to the original author(s) and the source, provide a link to the Creative Commons license, and indicate if changes were made.

The correct copyright holder and license text are:

- ㄷ UNU-WIDER. 2019 Open Access CC BY-NC-SA 3.0 IGO.

\section{Author details}

${ }^{1}$ International Fund for Agricultural Development, Rome, Italy. ${ }^{2}$ Department of Economics, University of Sussex, Falmer, UK.

Received: 21 January 2019 Accepted: 21 January 2019

Published online: 26 March 2019

\section{Reference}

Egger, Litchfield (2019) Following in their footsteps: an analysis of the impact of successive migration on rural household welfare in Ghana. IZA J Dev Migr 9:1 https://doi.org/10.1186/s40176-018-0136-4 